J. Clin. Chem. Clin. Biochem.

Vol. 15, 1977, pp. 361-366

\title{
An Experimental Model for Studies on the Effects of Food and Digestive Secretions on the Digestive-Absorptive Capacity of Rat Small Intestine ${ }^{1}$ )
}

\author{
By R. Ecknauer
}

Department of Clinical Chemistry, University of Ulm,

R. M. Clarke

Faculty of Medicine, University of Newcastle, Australia

and G. Feyerabend

Department of Surgery, University of Ulm

(Received September 17/December 6, 1976)

Summary: At an average of 32 days after a modified Roux-en-y repositioning of rat small intestine, the mucosal mass, mucosal composition, in vivo absorption of galactose and the activity of maltase, sucrase and alkaline phosphatase were measured. In the gut segment with digestive secretions but without food (A) the only change was a decrease of sucrase activity which occurred most probably at the cellular level. In the gut segment with food and gastric juice and a reflux of digestive secretions (B) complex changes took place. An increase in mucosal mass was not accompanied by an increase in galactose absorption. There was a high increase of sucrase activity, a moderate increase of maltase activity and a tendency of the alkaline phosphatase activity to decrease. The changes (increase in mucosal mass and total enzyme activity, but no changes in activity at the cellular level) in the segment exposed to both digestive secretions and food (C) were compatible with a more proximal promotion of a distal gut segment.

Ein experimentelles Modell zum Studium der Bedeutung von Nahrungs- und Verdauungssäften für die digestivabsorptive Leistung des Dünndarms der Ratte

Zusammenfassung: Durchschnittlich 32 Tage nach Anlegen einer Roux'schen Anastomose wurde im proximalen Dünndarm von Ratten die Masse der abschabbaren Mucosa, deren Zusammensetzung, die in vivo-Absorption von Galaktose sowie die Aktivität von Maltase, Sucrase und alkalischer Phosphatase im Homogenat der abgeschabten Mucosa gemessen. In dem Darmabschnitt mit Verdauungssäften jedoch ohne Nahrung (A) wurde als einzige Änderung ein Abfall der Sucreaseaktivität gefunden, welcher sehr wahrscheinlich auf der zellulären Ebene erfolgte. In dem Darmabschnitt mit Nahrung, Magensaft und einem Reflux von Verdauungssäften fanden wir einen Aktivitätsanstieg der Sucrase und in geringẹrem Ausmaße der Maltase. Die Verändẹungen in dem Darmabschnitt, der sowohl Nahrung als auch Verdauiungssäften ausgesetzt war (C) sind vereinbar mit einer mehr proximalen Verlagerung eines distalen Darmabschnittes.

\section{Introduction}

It is well known that the enzyme activity of the intestinal epithelium and the absorption of nutrients is strongly influenced by the availability and composition of food in the gut lumen (1-4) and by digestive secretions (5-11). In our experimental model a surgical re-

1) Supported by the "Deutsche Forschungsgemeinschaft". arrangement of the small intestine resulted in three different parts of small intestine, exposed either to digestive secretions or to food or to both.

\section{Methods}

A modified Roux-en-Y repositioning of the small intestine (1. c. (12) and fig. 1) was performed so that the most proximal segment A (average length $30 \mathrm{~cm}$ ) had only biliary and pancreatic input. The proximal end of the next segment (B) was anastomosed 
to the duodenal cap, and thus received food and gastric juice. Twenty $\mathrm{cm}$ further distally, the distal end of segment $\mathbf{A}$ was anastomosed end-to-side to the gut-in-continuity, and this anastomosis was the beginning of segment $\mathrm{C}$, which led to the ileocaecal valve. Shamoperated and unoperated rats were also studied, and each of these three groups contained seven animals. About 32 days ( $32 \pm 3$ days) after surgery the rats were starved "overnight" and received an i. p. pentobarbital (Nembutal, Abbott) anaesthesia. The gut segments A and B (fig. 1) were cannulated and perfused simultaneously at a rate of $12 \mathrm{ml} / \mathrm{h}$ for $70 \mathrm{~min}$. The perfusate was collected in 10 min fractions, the first two fractions being discarded. At the proximal part of the perfused segment the pressure was 3-5 cm fluid, at the distal part zero. At the end of perfusion the rats were killed by cervical dislocation, the perfused gut segments and the segment $C$ quickly removed, and rinsed with cold $\left(+4^{\circ} \mathrm{C}\right) 0.154 \mathrm{~mol} / 1 \mathrm{Na} \mathrm{Cl}$. After measuring the length by stretching with a $3 \mathrm{~g}$ weight, the gut segments were slit open longitudinally; the mucosa was scraped off with a glass-slide and immediately frozen $\left(-27^{\circ} \mathrm{C}\right)$. After freeze drying the mucosa was stored in a desiccator containing $\mathrm{CaCl}_{2}$ at $-27^{\circ} \mathrm{C}$. The previously described perfusion solution (13) was a diluted $R$ inger solution containing $64 \mathrm{mmol} D$-galactose (Fluka 48260 ), $5 \mathrm{ml}$ [ $\left.{ }^{14} \mathrm{C}\right] D$-galactose (Amersham Buchler CFA 242, specific activity: $3 \mathrm{mCi} / \mathrm{mmol}$ $=1116 \mathrm{~Bq} / \mathrm{mol}$, dissolved to $5 \mathrm{mCi} / 1=185 \mathrm{MBq} / \mathrm{l}$ ) and $20 \mathrm{mg}$ phenol red (Fluka 77650, MW 354.4) in one liter. Measurement of radioactivity and phenol red concentration in the perfusion solution and perfusates and calculation of the results were performed by established methods $(14,15)$. After weighing, the freeze dried mucosa was homogenized in a Potter Elvehjem homogenizer. In this homogenate the following parameters were measured: maltase (EC 3.2.1.20) and sucrase activity (EC 3.2.1.26) according to Böhmer et al. (7), alkaline phosphatase activity (EC 3.1.3.1) as described by Ecknauer (14) and proteinand DNA-content as described by Ecknauer \& Schnösenberg (16). The measurement of alkaline phosphatase activity, protein, DNA, and glucose concentration (after hydrolysis by disaccharidases) were subjected to a quality control (14).

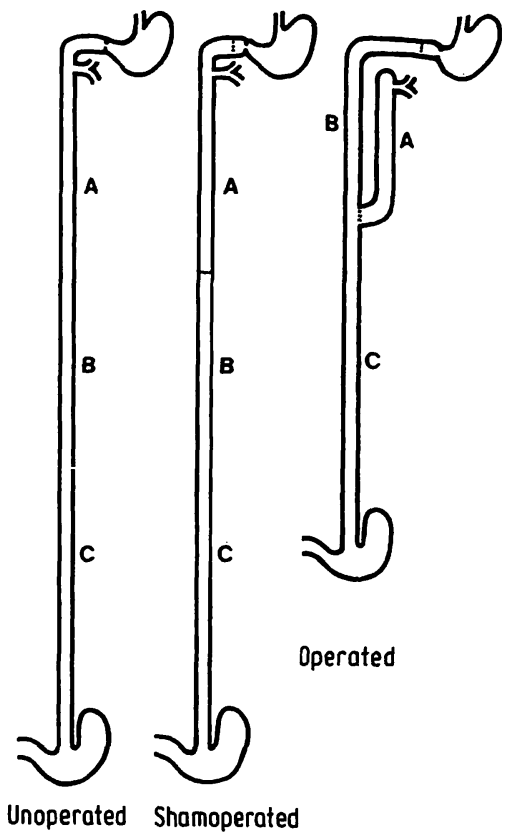

Fig. 1. Disposition of the small intestine.

A: First $20 \mathrm{~cm}$ segment starting at the ligament of Treitz. In the operated rat this segment contains only digestive secretions but no food.

B: Second $20 \mathrm{~cm}$ segment starting $20 \mathrm{~cm}$ distal to the ligament of Treitz. In the operated rat the stomach empties into this segment and bile and pancreatic juice can enter this segment only by reflux.

C: Third $20 \mathrm{~cm}$ segment starting about $40 \mathrm{~cm}$ distal to the ligament of Treitz. In the operated rat this segment contains both, food and digestive secretions.
The coefficient of variation in the series was:

$\begin{array}{ll}\text { Protein } & : 3.6 \text { and } 5.3 \% \text { (two sets of measurements) } \\ \text { DNA } & : 1.8 \text { and } 2.1 \% \text { (two sets of measurements) } \\ \text { Glucose } & : 0.8 \text { to } 1.9 \% \text { (eight sets of measurements) }\end{array}$

Alk. phosphatase: $6.4 \%$ (one set of measurements)

The coefficient of variation from day to day in our laboratory was:

Protein : $2.0 \%$

DNA : $5.1 \%$

Glucose: $4.8 \%$

For statistical analysis a two-tailed Wilcoxon-test for independent samples or for paired samples was used. If $2 \mathrm{P} \leqq 0.05$ was reached, a difference was called significant; otherwise an apparent difference, where indicated, was described as a "tendency", or the expression "seemed to be ..." wạs used.

\section{Results}

\section{General}

All rats appeared healthy and only one rat (operated) had an unformed stool at the time of investigation. Absorption and enzyme activity in this rat showed no difference from the other operated rats. Preoperative body weight showed no difference in the three animal groups (tab. 1). The post-operative weight gain (pre- and post-operative weight measured after "starvation overnight") was highest in the non-operated control rats, lower in the sham-operated control rats and lowest in the operated rats (tab. 1).

Wet and dry weight of the caecum cleaned from adhering contents was not influenced by sham-operation or operation (tab. 2).

Tab. 1. Initial body weight and weight change in the experimental groups.

Initial body weight and weight gain. All values represent an arithmetic mean with a standard deviation for 10 rats in each group. Differences in weight gain are significant.

\begin{tabular}{lccc}
\hline & $\begin{array}{l}\text { non- } \\
\text { operated }\end{array}$ & $\begin{array}{l}\text { sham- } \\
\text { operated }\end{array}$ & operated \\
\hline initial body weight $(\mathrm{g})$ & $197 \pm 14$ & $196 \pm 15$ & $202 \pm 16$ \\
total weight gain (g) & $137 \pm 31$ & $108 \pm 29$ & $92 \pm 19$ \\
$\begin{array}{l}\text { average daily weight } \\
\text { gain (g) }\end{array}$ & $4.4 \pm 1.3$ & $3.5 \pm 1.1$ & $2.9 \pm 0.8$ \\
\hline
\end{tabular}

Tab. 2. Wet and dry weight of the caecal wall. Wet- and dry weight of caecal wall. All values represent an arithmetic mean with a standard deviation from 8 rats in each group. No significant differences.

\begin{tabular}{llll}
\hline & $\begin{array}{l}\text { non- } \\
\text { operated }\end{array}$ & $\begin{array}{l}\text { sham- } \\
\text { operated }\end{array}$ & \multicolumn{1}{l}{ operated } \\
\hline wet weight $(\mathrm{g})$ & $1.29 \pm 0.14$ & $1.37 \pm 0.15$ & $1.24 \pm 0.06$ \\
dry weight $(\mathrm{g})$ & $0.249 \pm 0.024$ & $0.249 \pm 0.021$ & $0.252 \pm 0.02$ \\
\hline
\end{tabular}




\section{Mucosa}

There was no difference in "mucosal mass" between the non-operated and the sham-operated control rats, irrespective of whether this was expressed as dry weight of the scraped mucosa or expressed as protein or DNA-content per unit length. There was a tendency to a lower mucosal mass in gut segment $B$ in the sham operated rats, but the difference from the non-operated was not significant (fig. 2). The ope rated rats clearly showed a higher mucosal mass in segment $B$ and $C$ and no change in mucosal mass in segment $A$ as compared with the control groups (fig. 2). The overall composition of the mucosa expressed as protein or DNA content per unit dry weight of mucosa or the protein DNA ratio was not altered by sham. operation or operation (fig. 3).

\section{In vivo absorption}

Neither sham-operation nor operation influenced the disappearance of galactose from a $64 \mathrm{mmol}$ galactosesolution in segment A or B, irrespective of the reference system (fig. 4).
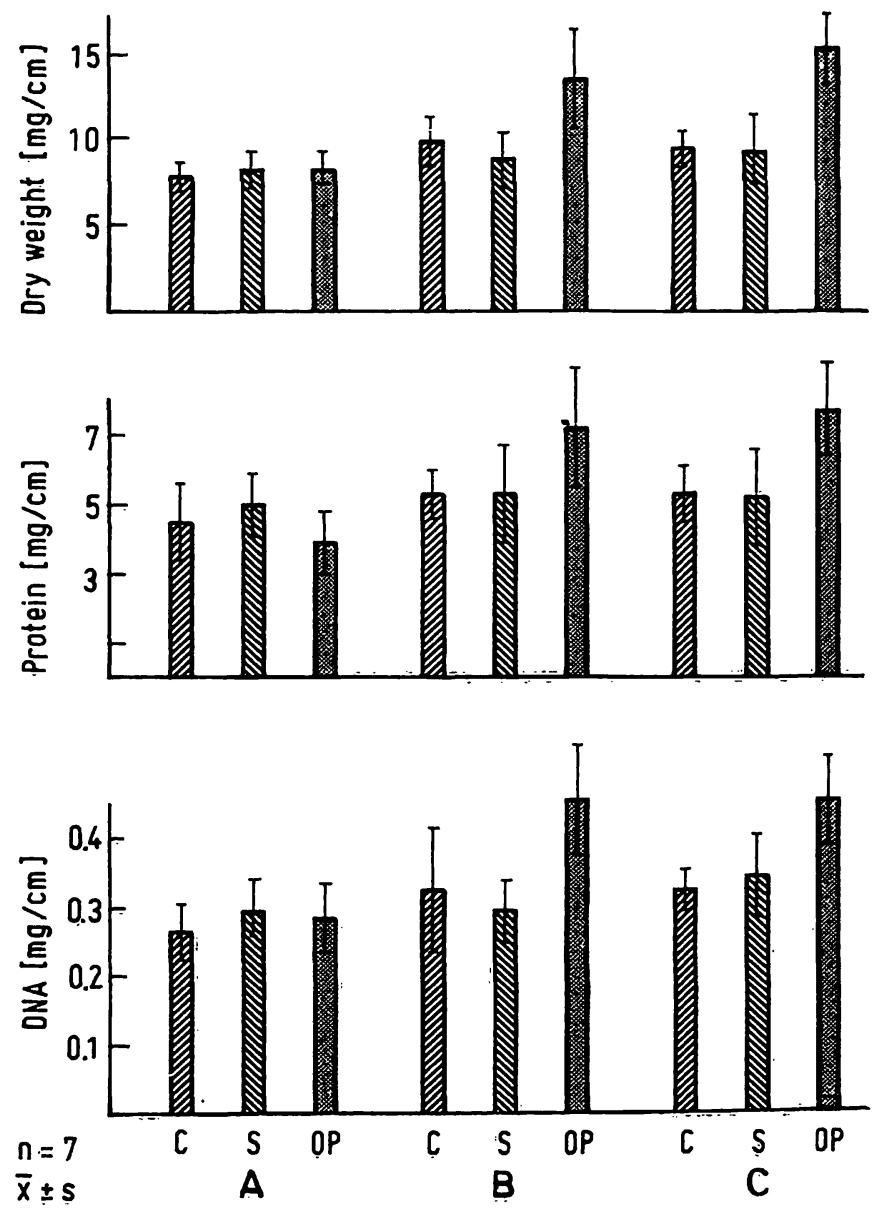

Fig. 2. Mucósal scrapings dry weight, protein and DNA content per unit gut length. There is no significant difference in the two control groups, the differences between operated rats and control groups in segment $B$ and $C$ are significant. C: Non-operated control rat

S: Sham-operated control rat OP: Operated rat (Roux-en-Y repositioning)
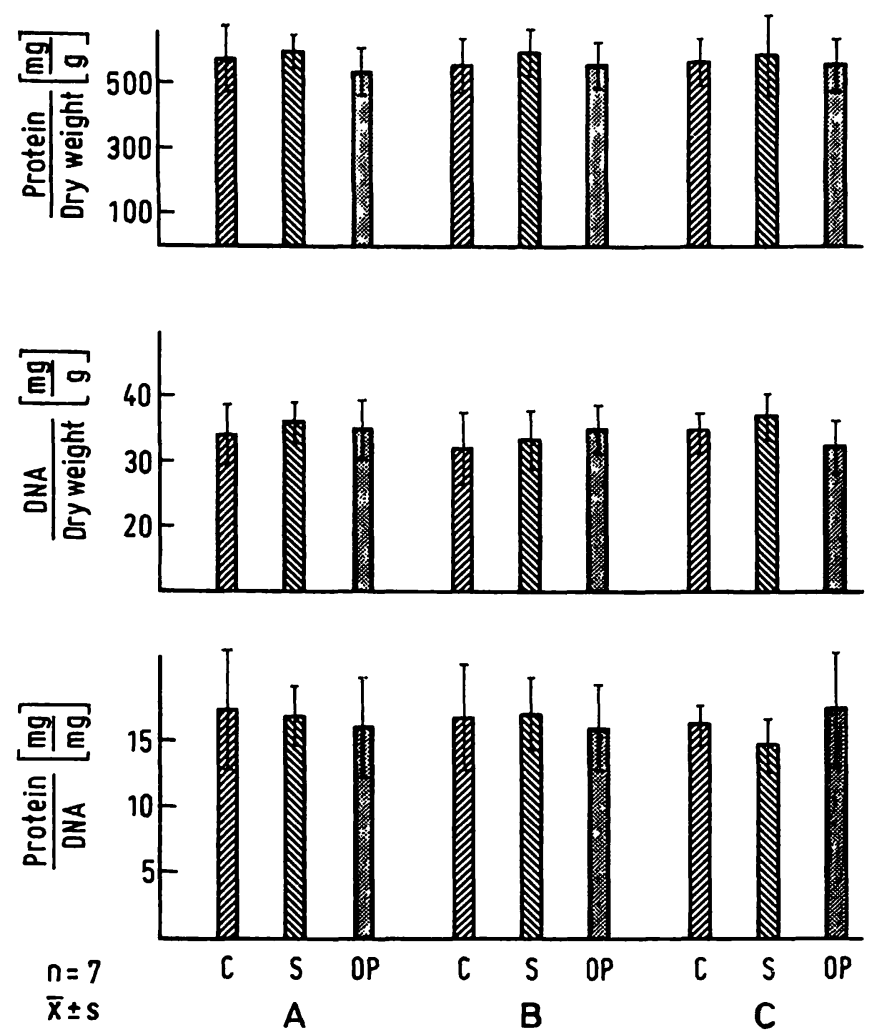

Fig. 3. Mucosal scrapings protein and DNA content per unit dry weight. Protein DNA ratio in the mucosal scrapings. No significant differences. Abbreviations as in Figure 2.
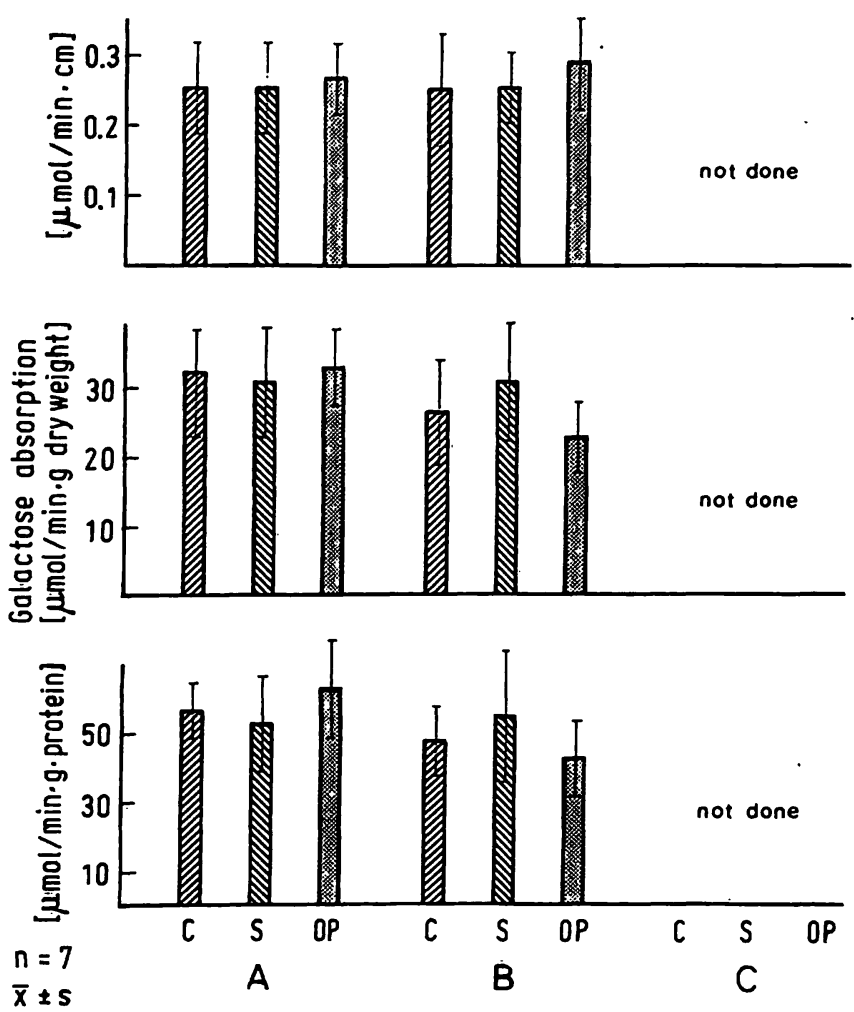

Fig. 4. In vivo absorption of galactose from a $64 \mathrm{mmol}$ solution. Absorption is expressed as $\mu \mathrm{mol}$ galactose disappeared per $1 \mathrm{~min}$ per reference system. Neither sham-operation nor operation caused significant differences. Abbreviations as in Figure 2. 
Activity of the "brush border enzymes"

\section{Sham-operation}

Sham-operation did not change the activity of the three enzymes referred to gut length nor the specific activity of these enzymes (fig. 5, 6 and 7).
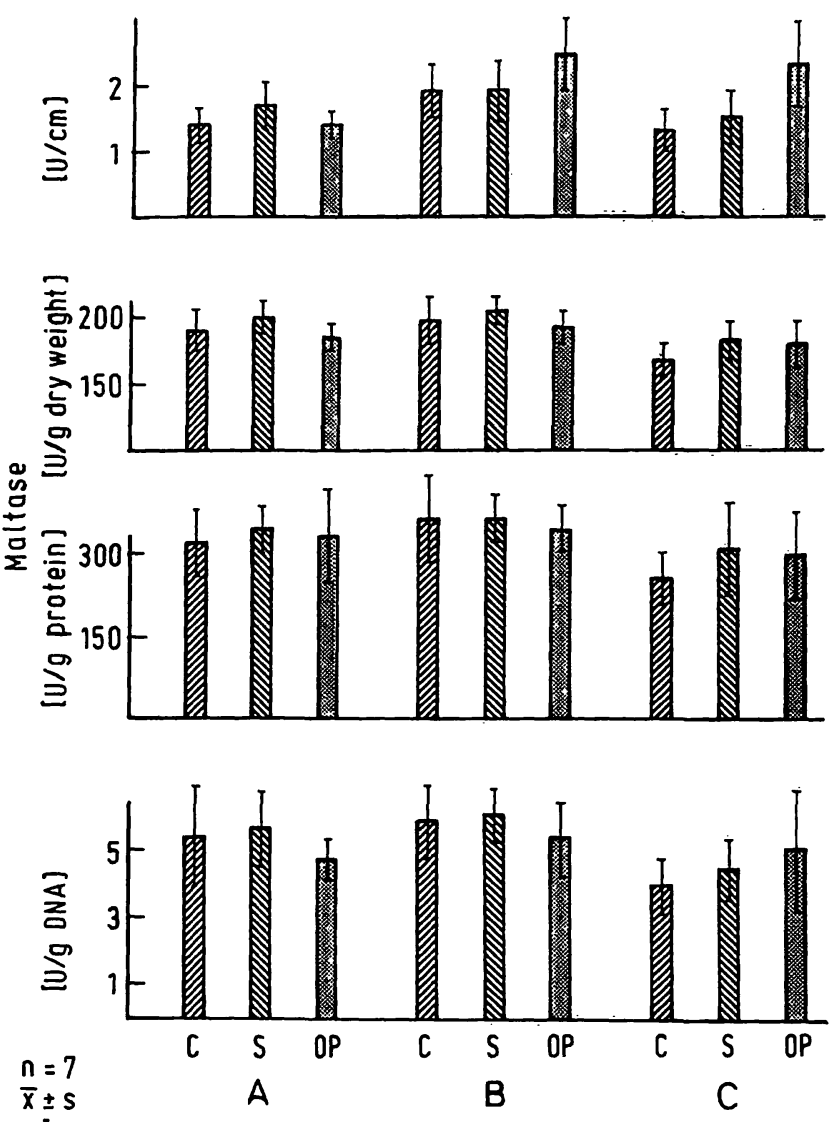

Fig. 5. Activity of maltase in the whole homogenate of the mucosal scrapings. In segment B the only significant difference in maltase activity per gut length is between non-operated and operated rats. In segment $C$ maltase activity per gut length in operated rats differs significantly from the control groups. Specific activity shows no significant differences. Abbreviations as in Figure 2.

\section{Operation}

In gut segment $\mathrm{A}$ there was a decrease of sucrase activity in all four reference systems. Alkaline phosphatase activity showed the same tendency but the differences were not significant. Maltase activity did not change. In gut segment $C$ the activity per gut length of all three enzymes rose (not significantly for alkaline phosphatase) but activity per mucosal mass remained unchanged. In gut segment B sucrase activity per gut length increased almost two-fold but showed only a moderate increase.in activity per mucosal mass when compared to the sham operated rats. Maltase-activity per gut length rose only when compared to non-operated controls, with no change or even a tendency to decrease in activity per mucosal mass. Alkaline phosphatase activity per gut length did not change, while activity referred to mucosal dry weight showed a tendency to decrease.
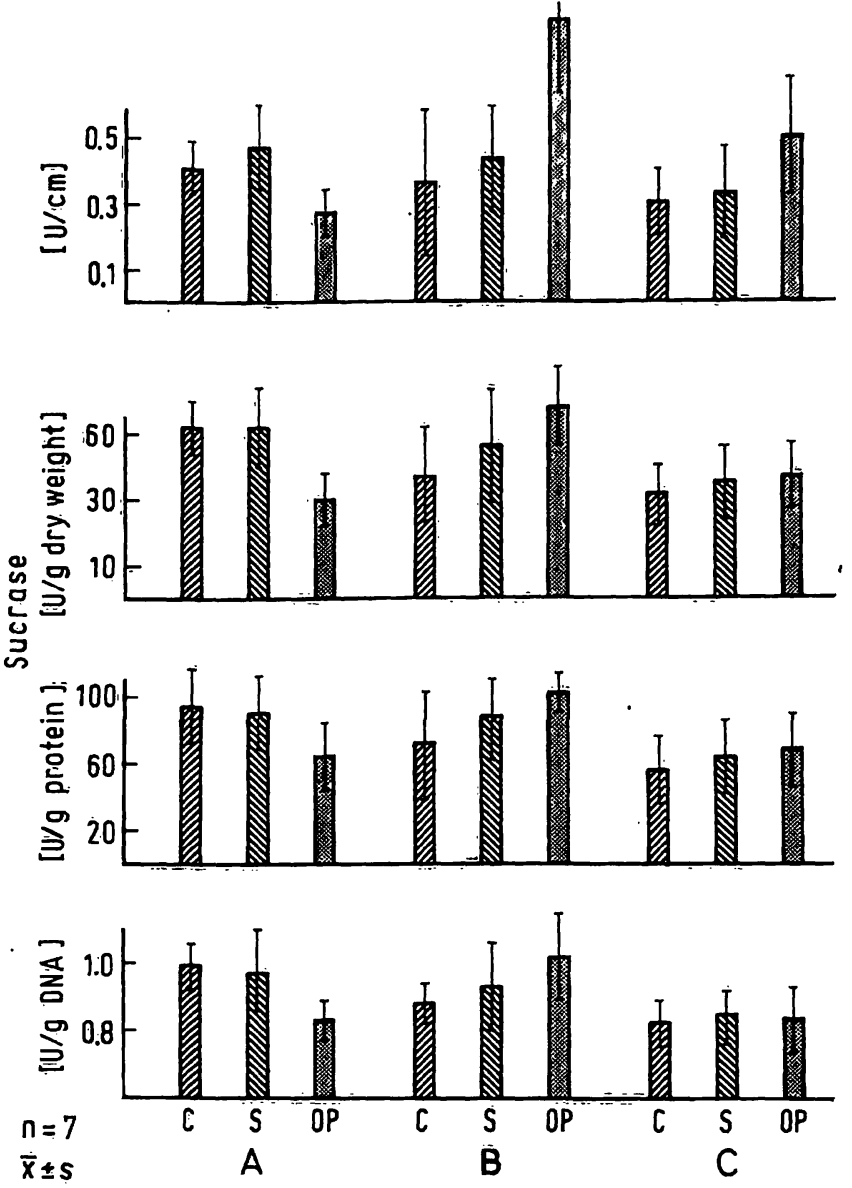

Fig. 6. Activity of sucrase in the whole homogenate of the mucosal scrapings. In segment A activity is significantly decreased in operated rats in all reference systems; with no change in sham-operated rats. In segment B activity per gut length in operated rats differs significantly from both control groups; the specific activity, however, differs significantly only from the non-operated rats: Sham operation caused no significant differences. In segment $C$ operated rats have a significantly higher activity per gut length than both control groups; specific activity is not changed significantly. Abbreviations as in Figure 2.

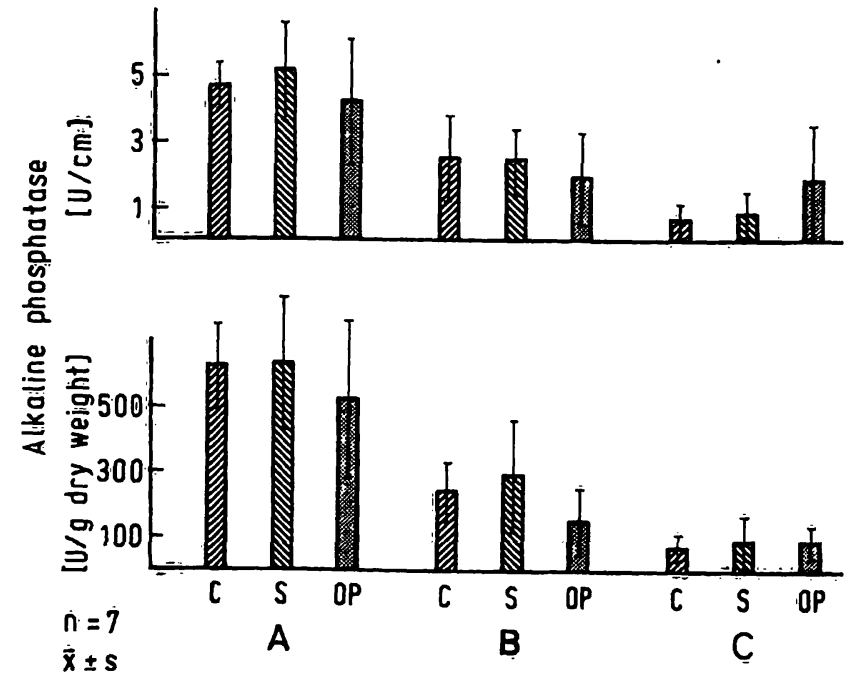

Fig. 7. Activity of alkaline phosphatase in the whole homogenate of the mucosal scrapings. Neither operation nor sham operation caused significant changes. Abbreviations as in Figure 2. 


\section{Discussion}

The changes in enzyme activities and the unchanged galactose absorption suggest that the small intestine is functioning relatively normally. This is also suggested by the unchanged caecal weight which can be increased when more nutrients reach the large intestine $(17,18)$.

In the present investigation we tried to estimate the mucosal mass by weighing the scraped mucosa and measuring its protein- and DNA content. In this study mucosal dry weight, mucosal protein and mucosal DNA behaved in a very similar way so that they were subsumed under the phrase "mucosal mass". The measurements of the "mucosal mass" were consistent with the morphological findings (12) in the segment without food (A) and the segment with both, food and digestive secretions (C). In the latter segment the increase of "mucosal mass" agrees well with similar measurements after proximal resection $(19,20)$. The high increase in gut circumference (Fig. 8) of the segment with digestive secretions only by reflux and food (B) caused an increase in "mucosal mass" in spite of only small changes of villus height (12).

In the present measurement of absorption we tried to get information on the maximal absorptive capacity of the intestine and used a high concentration of galactose (64 mmol/l) which is in the order of magnitude of the apparent $K_{\mathrm{m}}$ in vivo $(57.7 \mathrm{mmol} / \mathrm{l},(31)$ ) in rat jejunum. At this concentration there is "no significant passive transfer component of galactose" (31) and it can be assumed that the disappearance of galactose in the present study was due to active carrier mediated transfer. Under these conditions neither sham-operation nor operation caused a change of galactose absorption from the gut lumen in segment A or B. In spite of reports on the influence of nutrition on transport capacity $(3,22$, 23), the lack of food in segment $A$ does not result in smaller absorption rates. In the segment with digestive secretions only by reflux and food (B) perhaps the increase in serosal surface, as indicated by the increased circumference (Fig. 8) and the unchanged length (12) and therefore in mucosal surface, balanced a reduction of absorption due to the shortening of the villi at the proximal part of this segment (12). Furtheron the reflux of digestive secretions might be of importance in maintaining an unchanged absorptive capacity in this sègment.

The use of the reference system gut length offers information on the functional capacity of a gut segment but cannot answer whether or not a change in functional capacity is only due to a change in number of absorbing cells ("mucosal masss"). The reference system "mucosal mass" helps to differentiate functional changes at the "cellular level" from functional changes resulting from an altered cell number. The decrease of sucrase activity in the segment without food (A) represents, as indicated

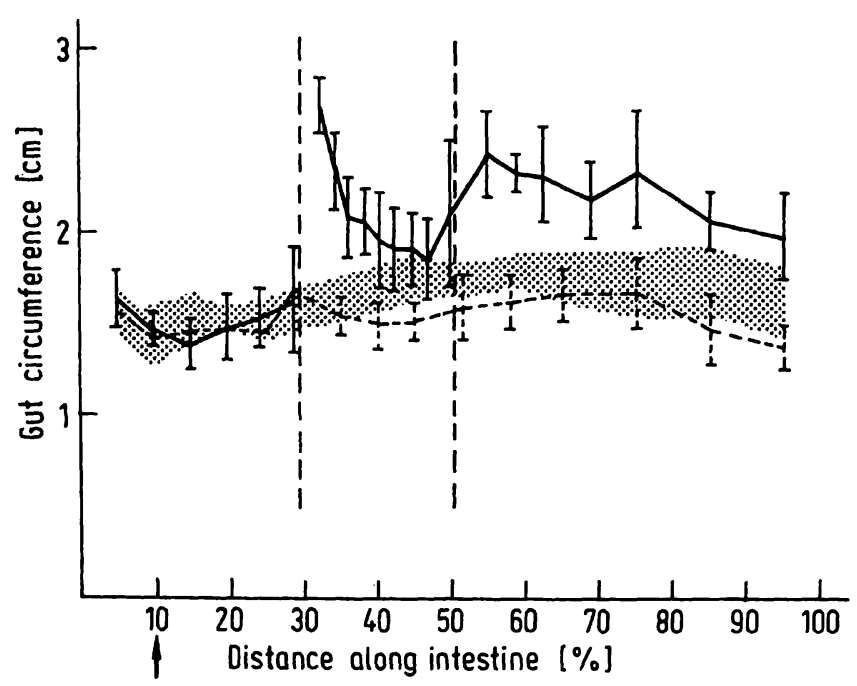

Fig. 8. Gut circumference, arithmetic mean with standard deviation. The shaded area shows the range $\bar{x}+s$ and $\bar{x}-s$ in the non-operated control rats. The dotted line derives from the sham-operated rats. Standard deviation is omitted up to $30 \%$ distance along the intestine in these rats. The continuous line with standard deviation and an interruption at $30 \%$ distance along the intestine derives from the operated rats. These measurements were made in the experiment of Clarke et al. (12) at the same sites at which these authors examined the intestinal wall, and at additional sites lying between those landmarks.

from the reference system, changes at the cellular level. Regarding the unchanged mucosal morphology and cell renewal it may be suggested that the digestive secretions maintain normal morphology and cell renewal $(5,12)$, but that the activity of enzymes is subject to further influences, in the present case perhaps to the availability of luminal carbohydrates $(2,24)$. Alpers \& Tedesco (6) could demonstrate that pancreatic proteases play an essential role in the turnover of the brush border enzymes $(6,8)$. It may be possible that in the lumen of segment $A$ the pancreatic enzymes, not mixed with food, release sucrase to a greater extent than in the two control groups.

The increased activity of all three enzymes in the segment with both food and digestive secretions (C) might be due mainly to mucosal hyperplasia (no, or only small changes at the cellular level). These changes can best be explained by advancing a distal gut segment to a more proximal position as it occurs in intestinal resection $(27,28)$. Histochemical studies showed no consistent change in the intensity of the staining reaction for these enzymes after intestinal resection (29) and support the hypothesis of mucosal hyperplasia rather than increased activity at the cellular level. The changes in segment $B$ are complex and cannot be interpreted satisfactorily without differentiating the proximal and distal part. 
The turnover of the brush border enzymes is controlled by a number of different regulation-mechanisms $(25,26)$ and may respond to the altered availability of digestive secretions and damage by hydrochloric acid in different ways. The changes in mucosal mass and enzyme activities were most probably not due to changes in circulating gastrin levels. Brown et al. (30) could not find any changes in fasting serum gastrin content 8 weeks after by-pass operations in rats.

Although disaccharidases, for instance sucrase and isomaltase, are involved in sugar transport $(32,33)$, the measurement of the activity of these enzymes in mucosal homogenates is no substitute for measuring the sugar transport directly $(15,34)$. Mc Michael (34) and Böhmer (15) could not find any correlation between mucosal disaccharidase activity and the rates of disaccharide disappearance from the gut lumen in vivo. In the present experiments no correlation between disaccharidase activity (sucrase, maltase) and galactose absorption could be demonstrated independently of the reference system used. This result was expected from the findings of Storelli et al. (35) who could not show any influence of sucrase-isomaltase incorporated into a black lipid membrane on the transfer of monosaccharides through this membrane. In spite of the fact that galactose is not a constituent of the substrates for the disaccharidases measured it was used because it is transported by the same carrier as glucose (36), and its metabolism in the small intestine is extremely low (37).

\section{Acknowledgements}

This is the report from a multidisciplinary group (SFB 112 project E 4) investigating the interrelationship between luminal contents, and small intestinal epithelial cell turnover and function. The authors tank Prof. Dr. K. Rommel for his help and constructive criticism at all steps of this work and Miss $J$. Breitsameter and Miss I. Schnösenberg for their expert assistance.

\section{References}

1. Blair, D. G. R., Yakimetes, W. \& Tuba, J. (1963), Can. J. Biochem. Physiol. 41, 905-917.

2. Castro, G. A., Copeland, E. M., Dudrick, S. J. \& Johnson, L. R. (1975), J. Nutr. 10S, 776-781.

3. Debnam, E. S. \& Levin, R. J. (1973), J. Physiol. (London) $231,21 \mathrm{P}-23 \mathrm{P}$.

4. Rosensweig, N. S., Herman, R. H. \& Stifel, F. B. (1971), Am. J. Clin. Nutr. 24, 65-76.

5. Altmann, G. G. (1971), Am. J. Anat. 132, 167-177.

6. Alpers, D. H. \& Tedesco, F. J. (1975), Biochim. Biophys. Acta 401, 28-40.

7. Böhmer, R., Rommel, K., Goberna, R. \& Raptis, S. (1971), Clin. Chim. Acta 33, 61-67.

8. Caspary, W. F., Winckler, R., Lankisch, P. G. \& Creutzfeldt, W. (1975), Gut 16, 89-92.

9. Cook, R. M., Powell, P. M. \& Moog, F. (1973), Gastroenterology 64, 411-420.

10. Gracey, M., Houghton, M. \& Thomas, J. (1975), Gut 16, $53-56$.

11. Heller, R., Tawil, T. \& Weser, E. (1974), Clin. Res. 21 A.

12. Clarke, R. M., Ecknauer, R. \& Feyerabend, G. (1976), Gut, accepted for publication.

13. Ecknauer, R. (1976a) Experientia 32, 709-710.

14. Ecknauer, R. (1976b) Acta Hepato-Gastroenterol. 23, 365-371.

15. Böhmer, R. (1976), Habilitationsschrift, Universität Ulm

16. Ecknauer, R. \& Schnösenberg, I. (1975), Z. Gastroenterol. 13, 639-643.

17. Schedl, H. P. \& Wilson, H. D. (1971), J. Exp. Zool. 176, 487-495.

18. Cary, B. A. \& Sladen, G. E. (1976), Clin. Sci. Mol. Med. $50,27-28 \mathrm{P}$.

19. Gleeson, M. H., Dowling, R. H. \& Peters, T. J. (1972), Clin. Sci. 43, 743-757.
20. Mackinnon, A. M. (1973), Am. J. Dig. Dis. 18, 576-582.

21. Debnam, E. S. \& Levin, R. J. (1973), J. Physiol. (London) $231,21 \mathrm{P}-23 \mathrm{P}$

22. Feld man, E. J., Peters, T. J., Naughton J. Mc. \& Dowling, R. H., Gastroenterology 66, A 37/691.

23. McManus, J. P. \& Isselbacher, K. J. (1970), Gastroenterology $59,214-221$.

24. Menge, H., Werner, H., Lorenz-Meyer, H. \& Riecken, E. O. (1975), Gut 16, 462-467.

25. Grand, R. J., Chong, D. A. \& Isselbacher, K. J. (1972), Biochim. Biophys. Acta 261, 341-352.

26. James, W. P., Alpers, D. H., Gerber, J. E. \& Isselbacher, K. J. (1971), Biochim. Biophys. Acta 230, 194-203.

27. Bury, K. D. (1971), Surg. Forum 22, 367-369.

28. McCarthy, D. M. \& Kim, Y. S. (1973), J. Clin. Invest. 52, 942-951.

29. Dowling, R. H. \& Gleeson, M. H. (1973), Digestion 8, 176-190.

30. Bowen, J. C., Paddack, G. L., Bush, J. C., Wilson, R. J. \& Johnson, L. R. (1976), Gastroenterology 70, A-8/866.

31. Batt, R. M. \& Peters, T. J. (1976), Clin. Sci. Mol. Med. 50, 499-509.

32. Crane, R. K. (1975), Trans. Am. Microsc. Soc. 94, 529-544.

33. Semenza, G. (1967), Protides Biol. Fluids, Proc. Colloq. 15, 201-208.

34. McMichael, H. B. (1972), Acta Hepato-Gastroenterol. 19, 281-290.

35. Storelli, C., Vögeli, H. \& Semenza, G. (1972), FEBS Letters $24,287-292$.

36. Honegger, P. \& Semenza, G. (1973), Biochim. Biophys. Acta $318,390-410$.

37. Smyth, D. H. (1971), Philos. Trans. Roy. Soc. London, Ser. B. $262,121-130$.
Dr. R. Ecknauer

Department für Klinische Chemie Universität Ulm

Oberer Eselsberg

D-7900 Ulm 